\title{
Spatial analysis of groundwater quality mapping in hard rock area in the Akola and Buldhana districts of Maharashtra, India
}

\author{
Chaitanya B. Pande ${ }^{1} \cdot$ Kanak Moharir ${ }^{2}$
}

Received: 5 October 2016 / Accepted: 14 June 2018 / Published online: 25 June 2018

(c) The Author(s) 2018

\begin{abstract}
The study of groundwater quality parameters is most essential for irrigation and drinking water, and its quality is a serious problem around the study area. The spatial analysis of groundwater quality mapping is required and stimulated us to undertake a systematic work of groundwater quality parameters for suitable water exploration of crops and drinking purposes from bore wells and open wells in basaltic hard rock area. A detailed study of physico-chemical parameters composition of groundwater was performed from groundwater quality data of post-monsoon (December) in the year of 2013. The groundwater quality data were collected from 35 wells samples randomly distributed in area. GIS is a powerful tool for representation and analysis of spatial information related to groundwater resources management. To achieve this aim, the groundwater quality samples were analysed for the preparation of groundwater quality maps such as $\mathrm{pH}$, electrical conductivity, TDS, $\mathrm{Cl}$ and $\mathrm{Mg}$. The groundwater quality parameters were analysed for all the sampling locations using IWD interpolation techniques. In this study, groundwater quality values observed are minimum and maximum values of $\mathrm{pH}(6.2-8$ on scale), electrical conductivity (348-1598 S/cm), total dissolved solids $(268.32-707.95 \mathrm{mg} / \mathrm{l})$, carbonate $(0-30 \mathrm{mg} / \mathrm{l})$, bicarbonate $(0.9-58.9 \mathrm{mg} / \mathrm{l})$, chloride (1.15-28.36 mg/l), sulphate (17.4-105 mg/l), nitrate (0.4-6.0 mg/l), calcium (2.35-7.24 mg/l), magnesium (2.88-3.73 mg/l), sodium $(0.57-3.31 \mathrm{mg} / \mathrm{l})$, potassium $(0.26-1.2 \mathrm{mg} / \mathrm{l})$, sulphate $(0.5-4.64 \mathrm{mg} / \mathrm{l})$, bicarbonate ${ }^{+}$carbonate $(1.07-11.16 \mathrm{mg} / \mathrm{l})$ and carbonate $(0-0.79 \mathrm{mg} / \mathrm{l})$ in hard rock area. The spatial variation maps were derived and integrated through ARC GIS 10.3 software. The interpolation tool was used to obtain the spatial distribution of groundwater quality parameters in the basaltic hard rock area. Therefore, the result of groundwater analysis of large number of groundwater samples has been found to be suitable for drinking and irrigation purposes in the basaltic hard rock area.
\end{abstract}

Keywords Groundwater · Basaltic rock · GIS · Inverse distance weighted method and GPS

\section{Introduction}

Groundwater is the most important source of water for irrigation, drinking and national purposes in town as well as city. Groundwater pollution is one of the most main environmental and ecological issues in the current world (Vodela et al. 1997; Kanak Moharir et al. 2017). Groundwater quality depends on the parameters of refreshed water, atmospheric precipitation, and land surface water on subsurface geochemical processes. Time-based fluctuations in

Chaitanya B. Pande

chaitanay45@gmail.com

1 AICRP for Dryland Agriculture, Dr Panjabrao Deshmukh Krishi Vidyapeeth, Akola, Maharashtra, India

2 Department of Geology, Sant Gadge Baba Amravati University, Amravati, Maharashtra 444602, India the source and constitution of the recharged water, hydrologic and social factors may effect periodic changes in water quality parameters. The applications of naturally occurring physico-chemicals parameters such as $\mathrm{Ph}, \mathrm{Cl}, \mathrm{HCO}_{3}$, TDS do not change health at certain stages but may affect the suitability of irrigation and drinking groundwater. Element reactions effect of rock miners, weathering, soil, rainfall, dissolution, precipitation, mining area and additional linked processes generally takes place below the surface. Groundwater has regarded as the largest natural resource in the form of groundwater and surface water. Groundwater makes up about $20 \%$ of the world's fresh water resource, which is about $0.61 \%$ of the whole world's water, with oceans and permanent snow. Deterioration of groundwater quality due to different geogenic and anthropogenic activities is of great concern (Buchanan and Triantafilis 2009; CGWB 2010). Geochemical procedures are responsible for the

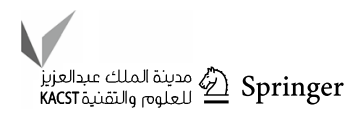



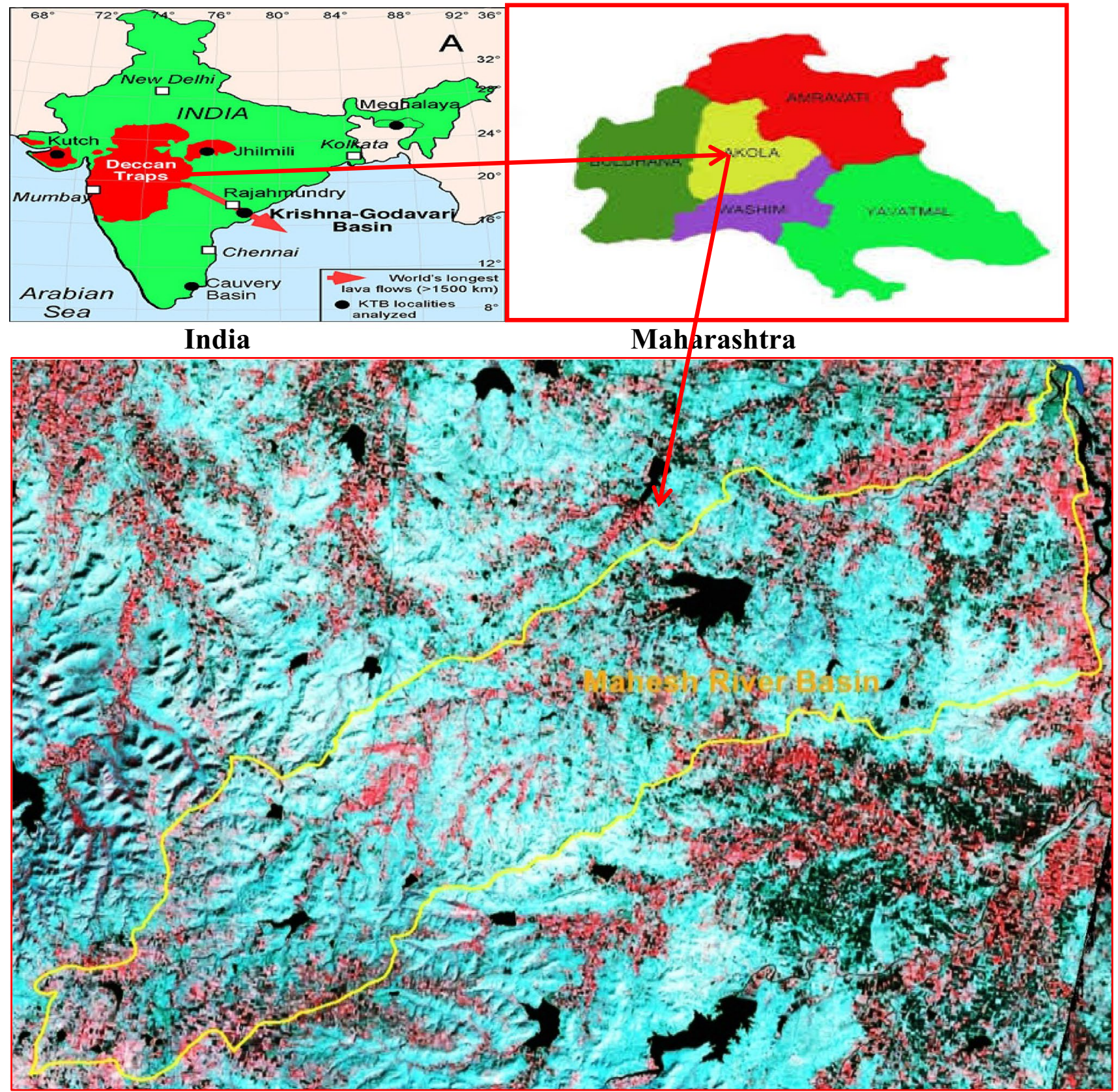

Fig. 1 Location map of Basaltic hard rock

periodic and variation in groundwater chemistry. In addition, the non-potable water quality of groundwater may be filtering of nutrient and relief of metals. The groundwater quality values play significant role for best suitability of wells for drinking and irrigation purposes in the hard rock region. The immigration of chemicals contaminants and the monitoring techniques of groundwater quality parameters are effective if the natural baseline quality is strongminded with a suitable degree of assurance. Anthropogenic activities can change the relative helps of the natural causes of variations and also introduce the effects of pollution (Whittemore et al. 1989; Sarath Prasanth et al. 2012; Arslan 2013). The knowledge of hydrochemistry is important to assess the groundwater quality in any area, in which the groundwater is used for both irrigation and drinking needs (Srinivas et al. 2013). Groundwater quality is based on various factors such as physical, chemical and biological factors. The use of spatial analysis has greatly simplified the 


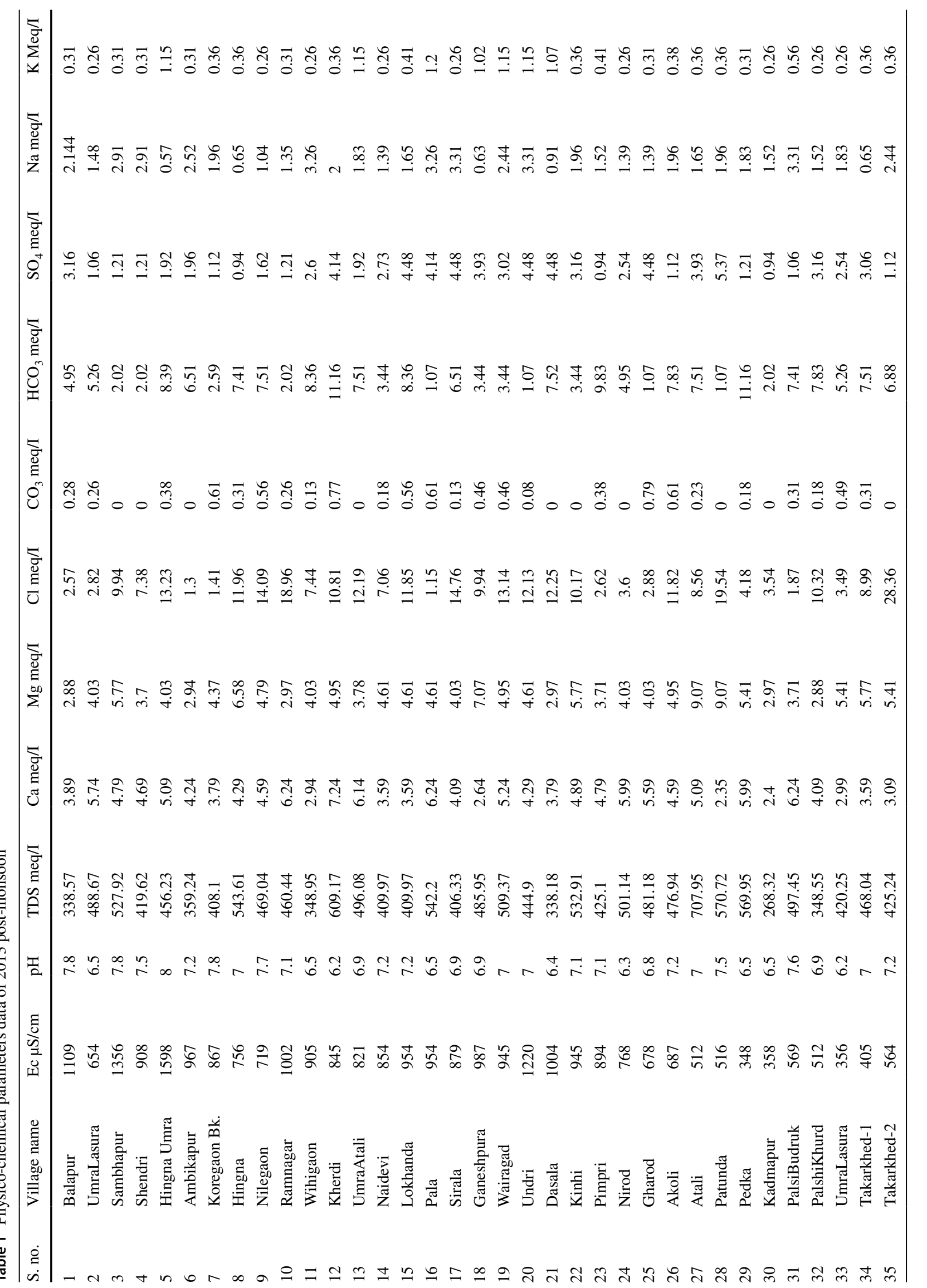




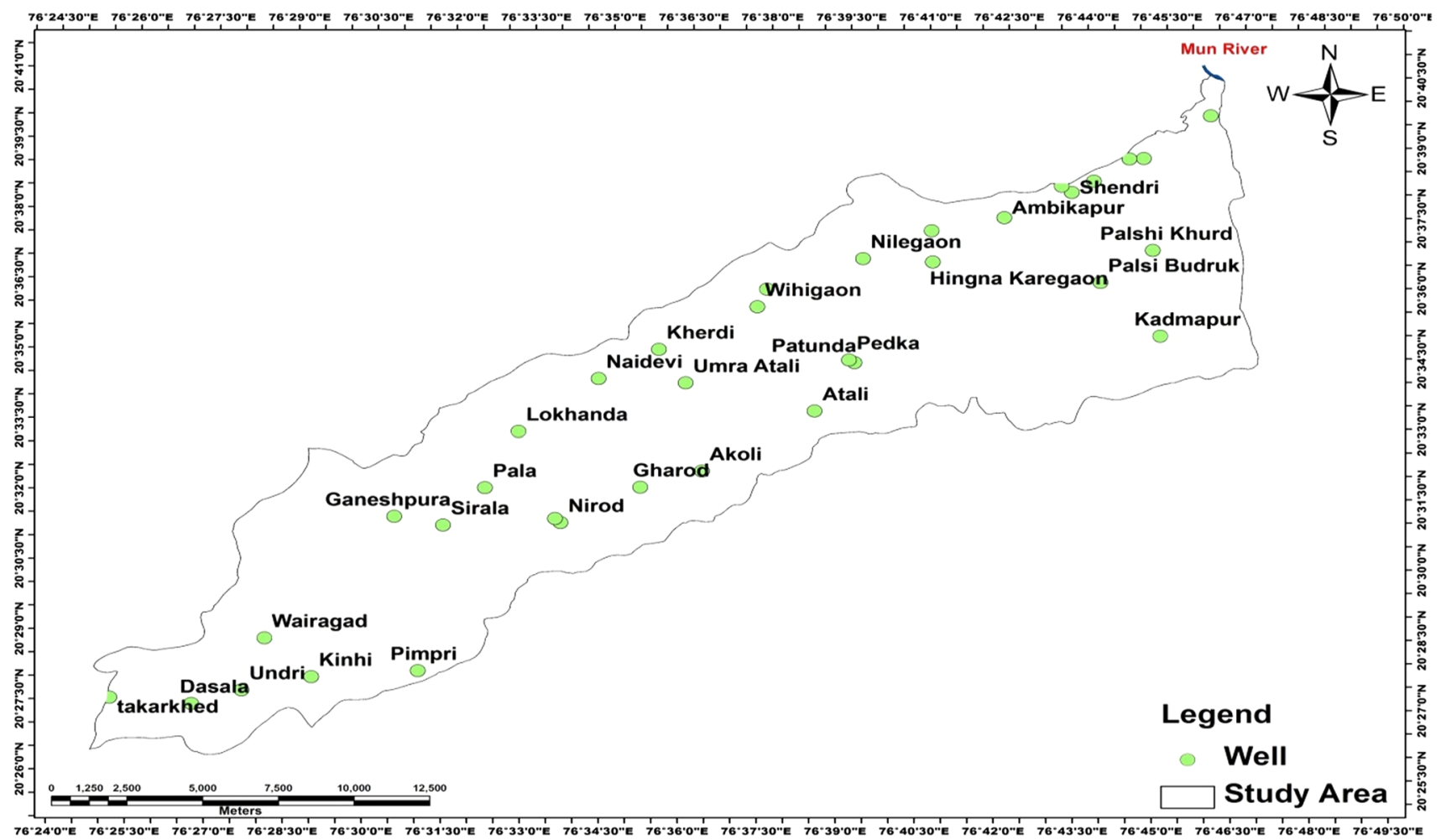

Fig. 2 Well location map of Basaltic hard rock

assessment of natural resources and environmental concerns including groundwater. The groundwater studies is used for site suitability analyses, managing site inventory data, estimation of groundwater vulnerability to contamination, groundwater flow modelling solute transport and leaching and integrating groundwater quality assessment models with spatial data to create spatial decision support systems using Arc GIS 10.3 software. Hence, observing surface and groundwater quality mapping has been required for affected saline zone area. The groundwater quality parameters have been depend on different parameters like $\mathrm{pH}$, electrical conductivity (EC), total dissolved solids, $\mathrm{Ca}, \mathrm{Mg}$, nitrate. (Gong et al. 2014; Khadri et al. 2013). The study of IDW interpolation techniques was used for the preparation of water quality maps based on the detection of favourable well sites which is based on the groundwater quality parameters. Many researches and planners related to earth sciences were carried out through spatial technologies. GIS software is an effective tool in water quality mapping and important for observing the environmental management and variation detection. As such, the objective of this study is to explore the hydro-geochemistry of the groundwater in different villages in the basaltic had rock area (El-Hames et al. 2011; Chen and Feng 2013).

\section{Study area}

The current study area is located in Akola and Buldhana Districts of Maharashtra in India. Study area is covered between $76^{\circ} 46^{\prime} 11^{\prime \prime} \mathrm{E}$ and longitude $20^{\circ} 40^{\prime} 36^{\prime \prime} \mathrm{N}$ latitude by Survey of India Toposheets nos. 55D/9, 55D/7, 55D/11, 55D/13, 55D/14 and 55 D/15with 1:50,000 scale. Study area is prepared from LISS-III satellite data with $23.5 \mathrm{~m}$ resolution. In this study, minimum and maximum elevation ranges such as 240 and $580 \mathrm{~m}$ elevation were notified from digital elevation model. Total area calculated is $328.25 \mathrm{Sq}$. kms using Arc GIS 10.3 software. The basaltic hard rock area is occupied by young and older alluvium patches. The land use land cover has changed significantly over the last years due to urbanization, waste land, mining and increase population. Out of the total area, nearly $75 \%$ is civilized, and the respite is occupied by built-up land, roads, river, forests, and so on. The study area has covered by thick vegetation and open forest area (Fig. 1). 


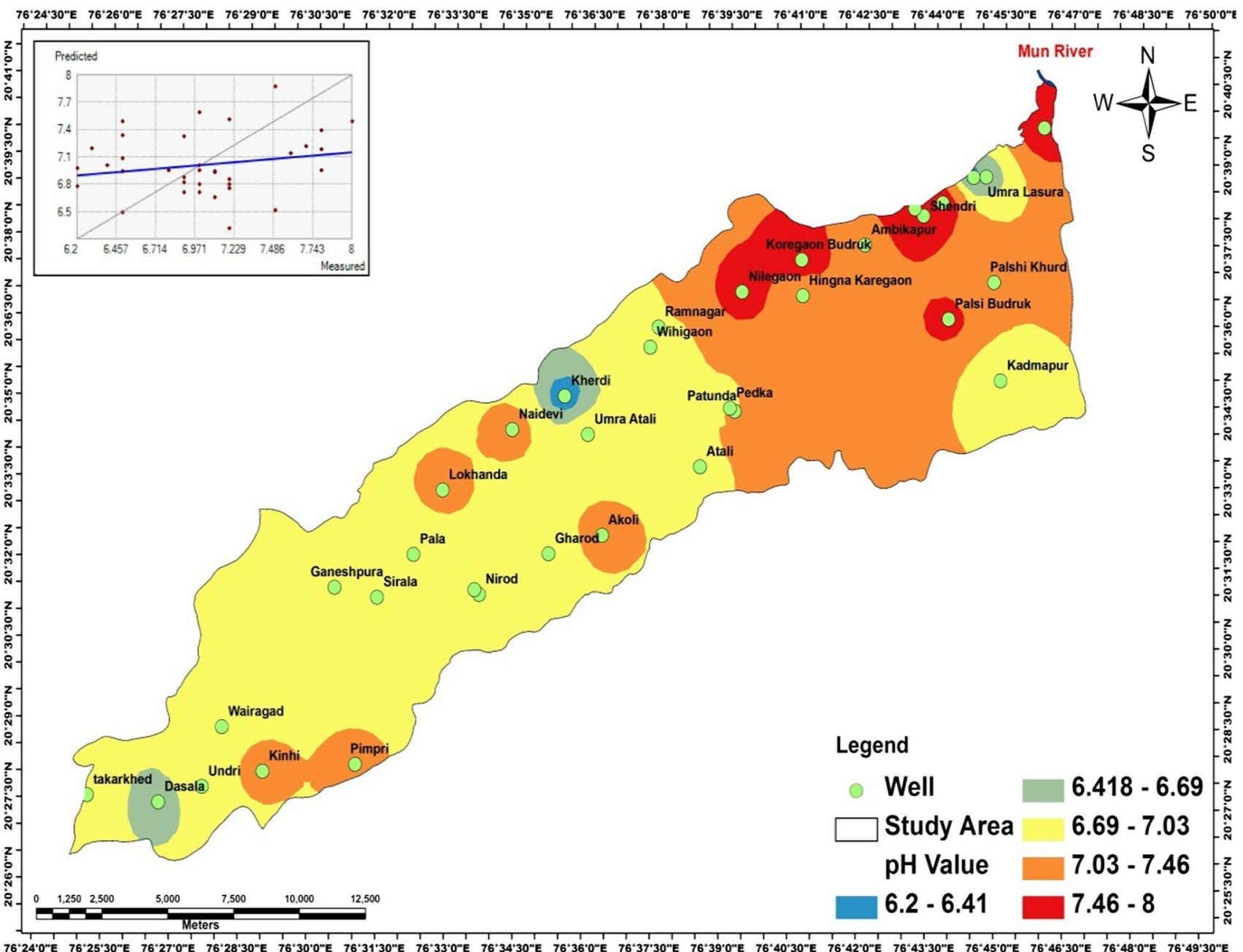

Fig. 3 Spatial distribution map of $\mathrm{pH}$ post 2013

\section{Methodology}

The survey of observation wells was fixed using GPS instruments and Arc GIS 10.3 software. Groundwater quality data were collected from open, bore and dug wells. The temperature of the groundwater samples was determined using a common mercury thermometer. $\mathrm{pH}$ and $\mathrm{EC}$ values were measured using a handheld multi-water quality probe (HANNA HI-9828, USA). All samples were labelled properly, and according to the prerequisites for the water quality parameters like EC, pH, TDS, Ca and Mg were analysed in the basaltic hard rock area. The groundwater quality monitoring for drinking purpose was assessed in terms of physical and chemical parameters based on Bureau of Indian Standards (BIS, 2000) (Table 1). The GARMIN GPS was used to locate the exact coordinates of the samples collection for regular water quality monitoring in the basaltic hard rock area. Thirty-five groundwater samples were collected from observation wells around study area (Fig. 2). The groundwater quality maps were prepared using inverse distance weighted (IDW) interpolation technique in ARC GIS 10.3 software. During field work, difficulty was experienced to measure water levels and collection of samples from some of the production wells due to continuous pumping and as a result, water samples were left out unintentionally. In this study, open wells and water bodies play an important role for groundwater recharge purposes in the basaltic hard rock 


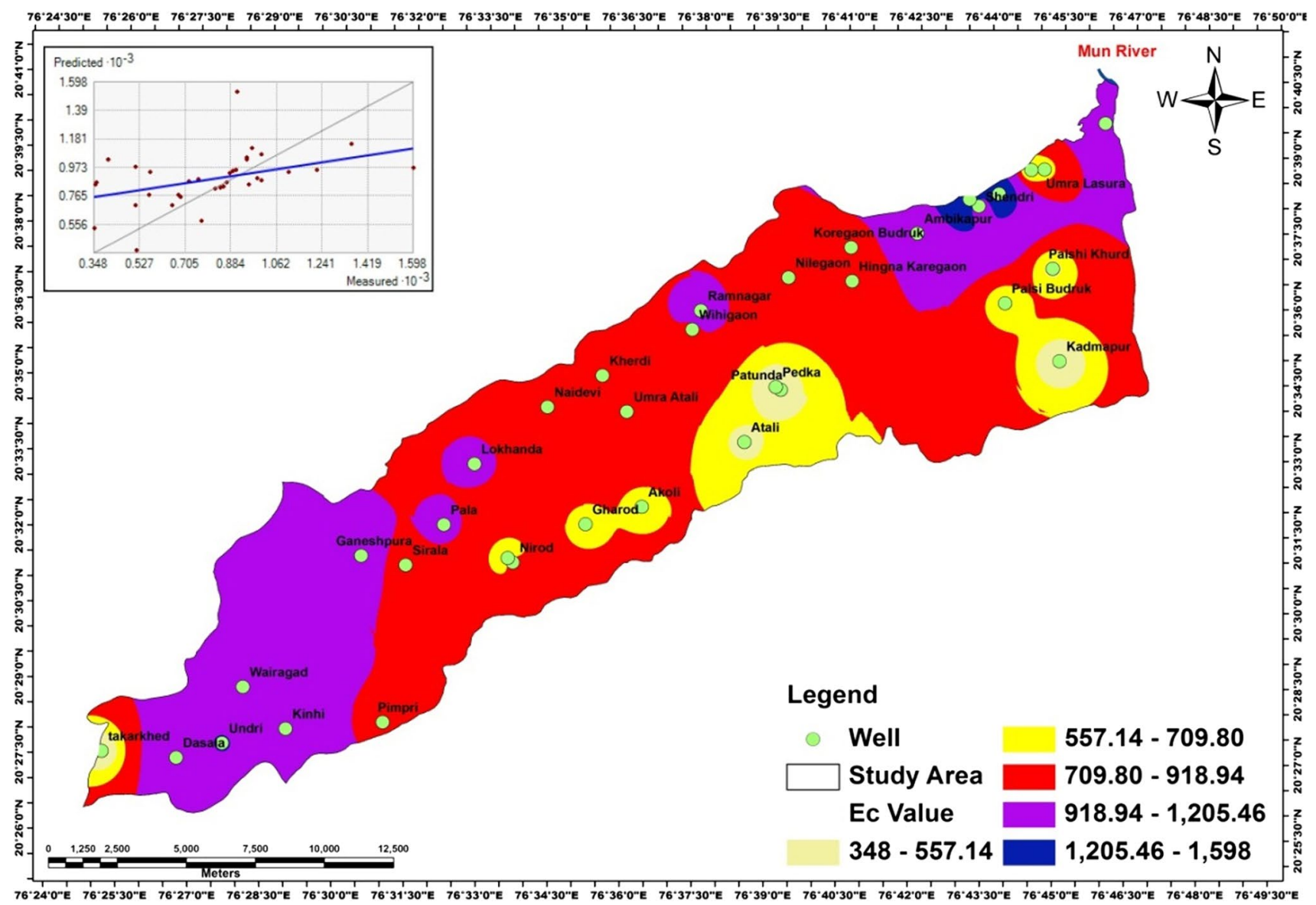

Fig. 4 Spatial distribution map of EC post 2013

area. Therefore, water samples were also collected from secondary sources using GPS instrument.

These large water bodies were constructed and provided for drinking and irrigation water requirement, but nowadays, water bodies are dry in the hard rock due to insufficient rainfall and climate change. Geographical information system (GIS) method is used to spatially represent water quality data sets for the purpose of generating maps and making spatial comparisons of data. Spatial analyst tools were the primary tool used to produce maps that aided analysis. The spatially integrated data and analytical results can be used for hydrological parameters. The spatial analysis of various physico-chemical parameters was carried out using the ARC GIS 10.1 software. The physico-chemical parameters of the analytical results were compared with standard guideline values recommended by the WHO.

\section{Water quality analysis}

Groundwater samples were collected, preserved and analysed as per standard methods (APHA 1998). A total of 35 water samples were collected during 2013 post-monsoon. Collected samples were analysed for physico-chemical parameters as $\mathrm{pH}$, total dissolved solid (TDS), total hardness, alkalinity, calcium (Ca), magnesium $(\mathrm{Mg})$, sulphate (SO4), nitrate $\left(\mathrm{NO}_{3}\right)$, chloride $(\mathrm{Cl})$, etc. (Table 1). Other parameters were analysed in the institute laboratory after completion of the sampling (Subramani et al. 2005).

\section{Groundwater quality mapping}

Spatial maps of $\mathrm{pH}, \mathrm{EC}$, TDS, $\mathrm{Na}$ and $\mathrm{Cl}$, and integrated maps of groundwater quality were produced using the inverse distance weighted (IDW) interpolation method of ARC GIS 10.1 


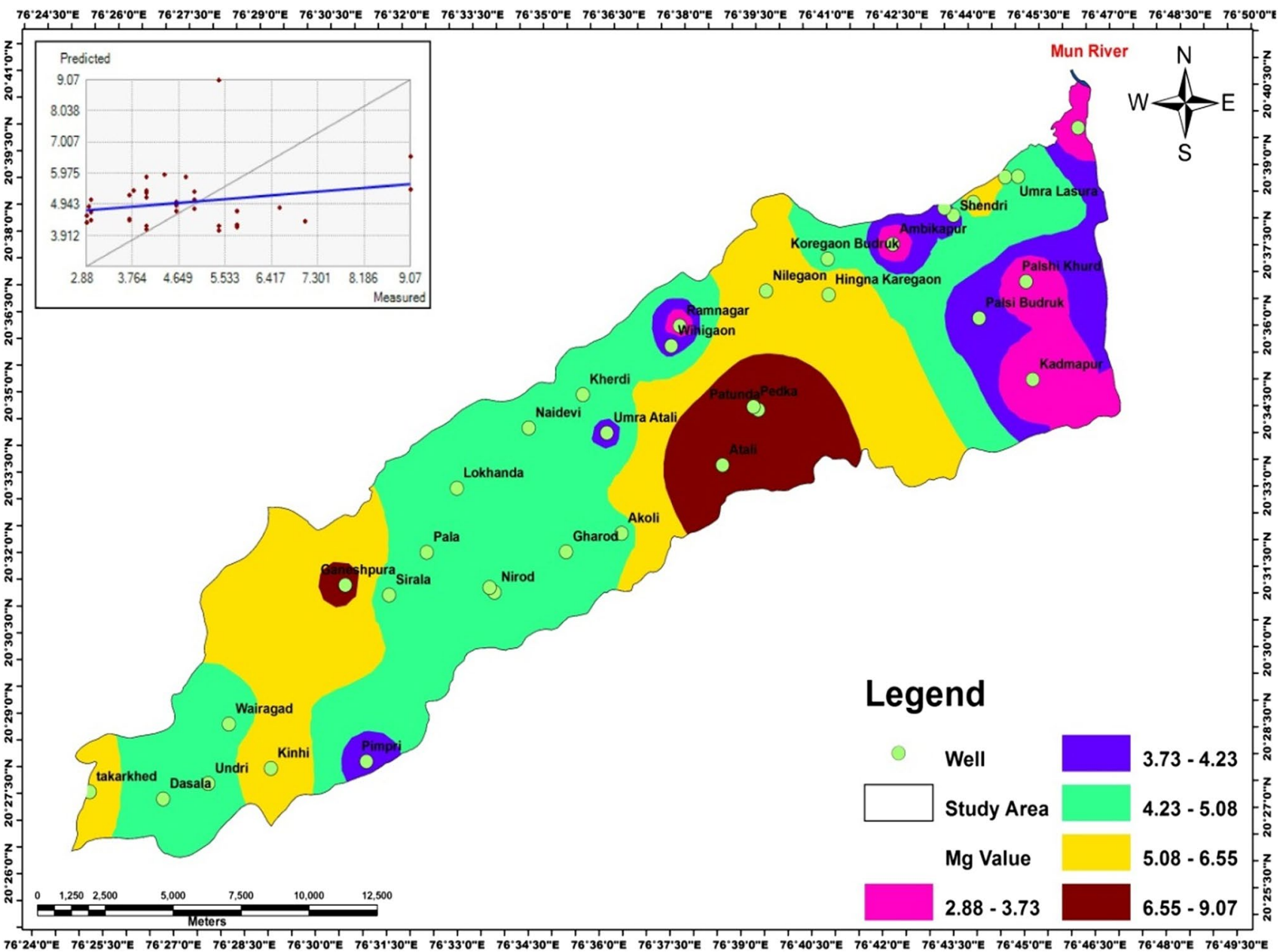

Fig. 5 Spatial distribution map of Mg post 2013

software. IDW is an algorithm to interpolate data spatially or estimate values between measurements. Estimates of IDW interpolation are the weighted averaged values of surrounding sample points. Weights are computed by the inverse of the distance from an observation to an estimate. The best results from IDW are obtained when sample points are sufficiently dense to represent the local variation. If the sample points are sparse or very uneven, the estimates may not adequately represent the desired variations (Burrough and McDonnell 1998; Selvam et al. 2014). Groundwater quality maps were generated based on the WHO (2004) and BIS (2000) drinking water standards.

Arc Map software 10.3 was used to map water quality values in unsampled locations. The basis of interpolation methods is that it assumes that values that are closer to one another are more alike than those that are farther away. Measured values surrounding an unmeasured location are used for prediction. Most popularly used interpolation methods, i.e., OK and IDW, are compared in this study for mapping groundwater quality parameters in the basaltic hard rock area (Vetrimurugan Elumalai et al. 2017).

\section{Results and discussion}

The spatial and the attribute database generated are integrated for the generation of spatial variation maps of major water quality parameters $\mathrm{Ec}, \mathrm{pH}$, TDS, $\mathrm{Ca}$ and $\mathrm{Mg}$, etc. Groundwater quality maps has been showed, which suitable wells for used of irrigation purpose at the hard rock area. In this study groundwater quality data were prepared using Arc GIS 10.3 software. This integration of the 


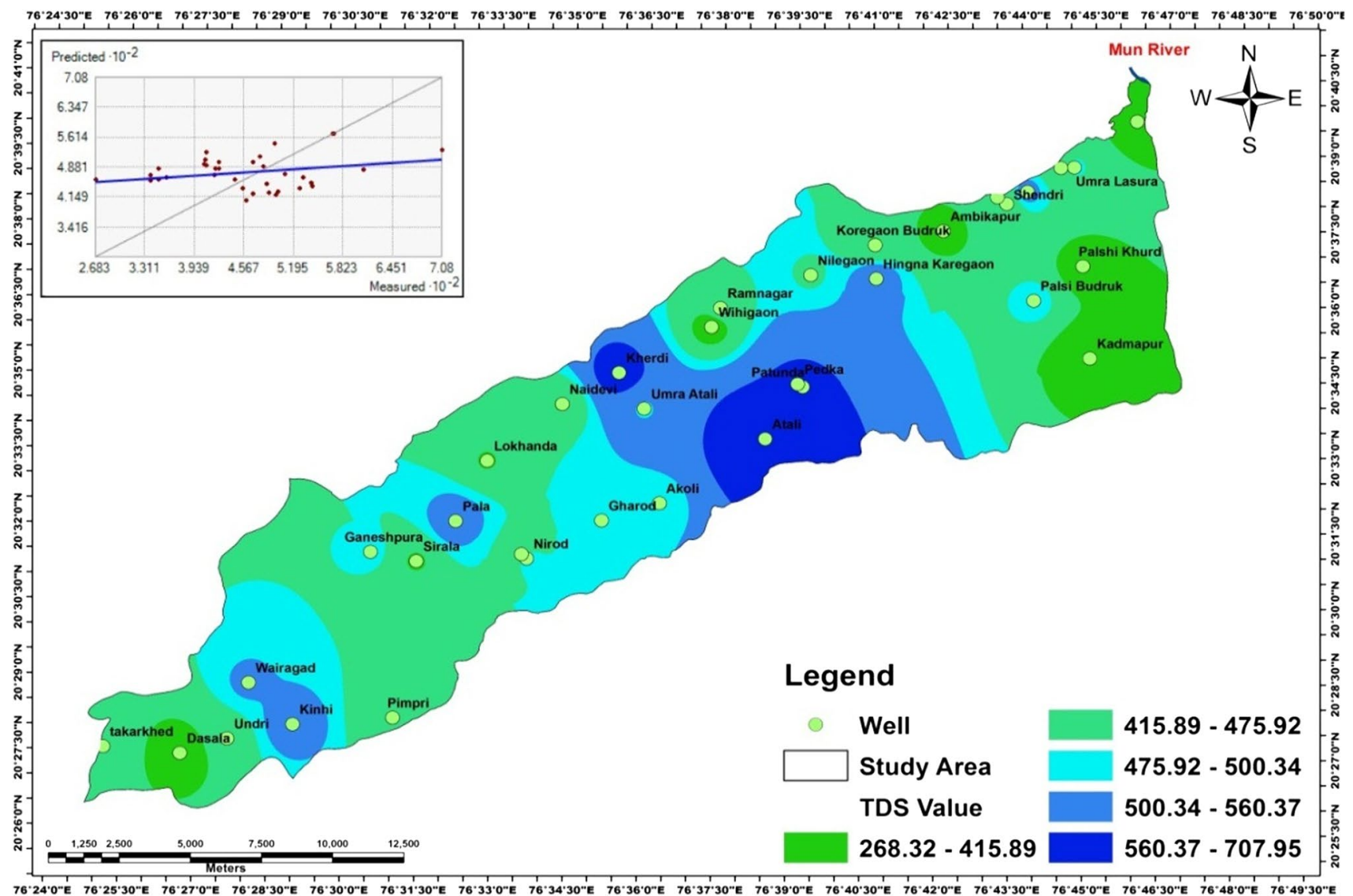

Fig. 6 Spatial distribution map of TDS post 2013

groundwater quality maps helps us to know the existing groundwater condition in the area.

\section{General hydrochemistry of groundwater}

\section{pH}

$\mathrm{pH}$ is one of the important parameters of water and determines the acidic and alkaline nature of water. The $\mathrm{pH}$ of the good quality water ranges from 7.5 to 7.9 (Fig. 3). The $\mathrm{pH}$ of the samples was well within the prescribed standards for drinking water. The spatial variation map for $\mathrm{pH}$ was prepared and presented the $\mathrm{pH}$ of analysed sample which varies from 6.2 to 8 for post-monsoon of 2013. The values of $\mathrm{pH}$ ranged from 7 to 9 . Minimum $\mathrm{pH}$ (7.25) was observed in Kherdi and Dasala village (Sample no-12 and 21), while maximum $\mathrm{pH}(8)$ was observed in
Palsi Bk. and Nilegaon village (Sample no-32 and 9) (Table 1).

\section{Electrical conductivity (EC)}

Electrical conductivity is the ability of a substance to conduct an electrical current, measured in micro-Siemen's per centimetre $(\mathrm{mS} / \mathrm{cm})$. Ions such as sodium, potassium, chloride give water its ability to conduct electricity. Conductivity is an indicator of the amount of dissolved salts in a stream which is often used to estimate the amount of total dissolved solids (TDS) rather than measuring each dissolved constituent separately. The ability of a cube $1 \mathrm{~cm}$ on a side to conduct an electrical current is called electrical conductivity; this is the reciprocal of resistivity and is measured in mhos. Since mho is too large, a unit for fresh water, micromho is used. This is a function of temperature, the kind of ions present and the concentration of 


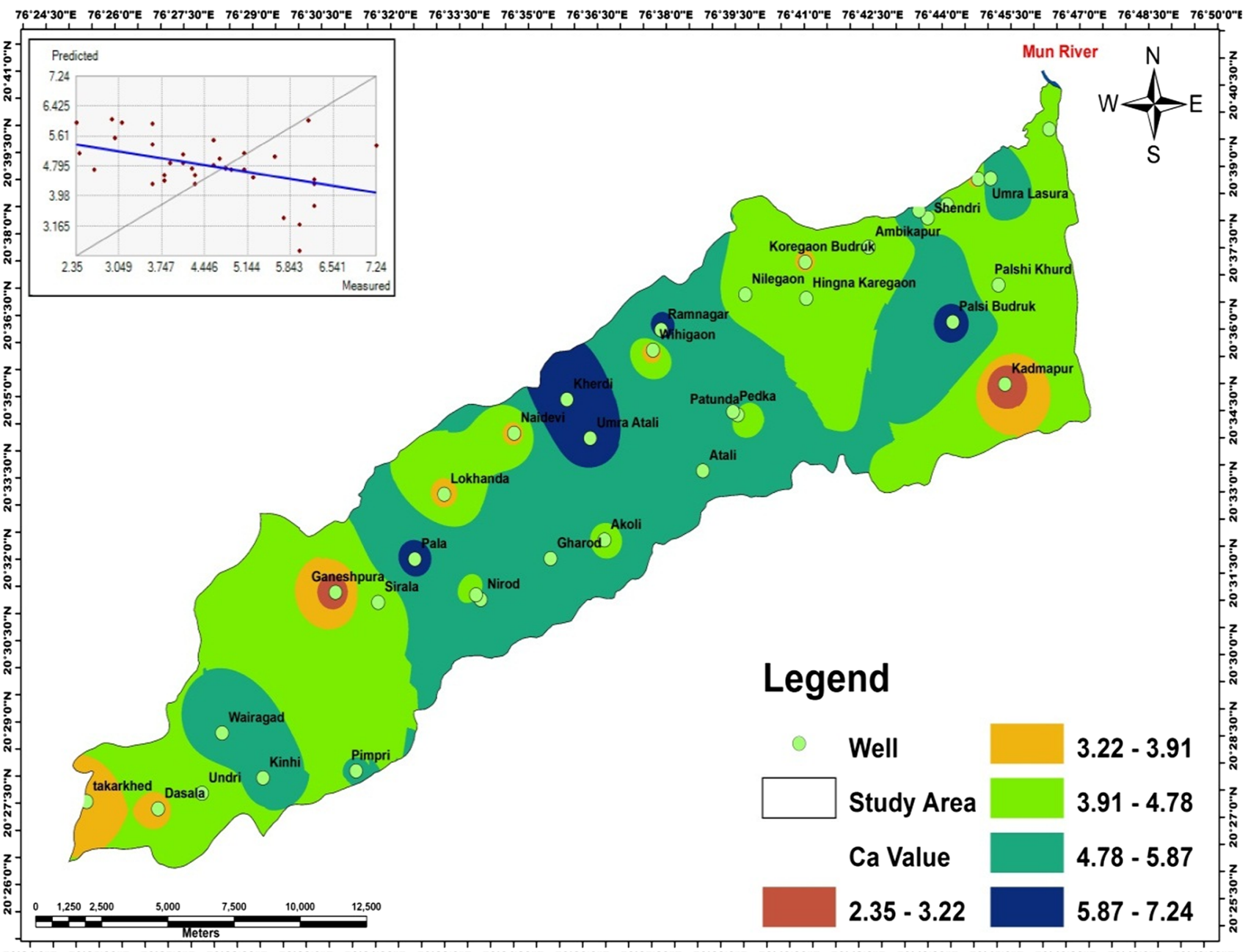

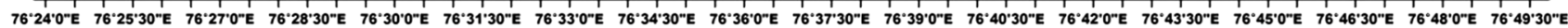

Fig. 7 Spatial distribution map of Ca post 2013

other ions. Hence, the unit is in micromhos $/ \mathrm{cm}$ at $25{ }^{\circ} \mathrm{C}$. In the present study, minimum $(348 \mu \mathrm{mhos} / \mathrm{cm})$ in western and southern part of the basin and maximum (1598 $\mu \mathrm{mhos} / \mathrm{cm}$ ) in northern and western part in the basin by analysing the results, all water samples showed EC higher than permissible limit (Fig. 4).

\section{Magnesium (Mg)}

In this study, magnesium and calcium are the two elements mainly responsible for hardness water. Olivine, biotite, horn blend, serpentine are some major magnesium-bearing minerals. The presence of carbon dioxide influences the solubility of magnesium. The desirable limit of magnesium in natural water is $30 \mathrm{mg} / \mathrm{l}$.
The observation of the $\mathrm{Mg}$ value in study area ranges between 2.88-3.75 and 6.55-9.07 for post-monsoon 2013. Minimum Mg (2.88) was observed in Palsi Kh. and Plasi Bk. villages, while maximum $\mathrm{Mg}$ (9.07) was observed in Atali and Nilegaon Pedka villages (Fig. 5).

\section{Total dissolved solids}

The mineral constituents dissolved in water constitute dissolved solids. The concentration of dissolved solids in natural water is usually less than $500 \mathrm{mg} / \mathrm{l}$, while water with more than $500 \mathrm{mg} / \mathrm{l}$ is undesirable for drinking and many industrial uses (Fig. 6). Water with TDS less than $300 \mathrm{mg} / \mathrm{l}$ is desirable for dyeing of cloths and the manufacture of plastics, pulp paper, etc. The total concentration of dissolved minerals in water is a general indication of the over-all 


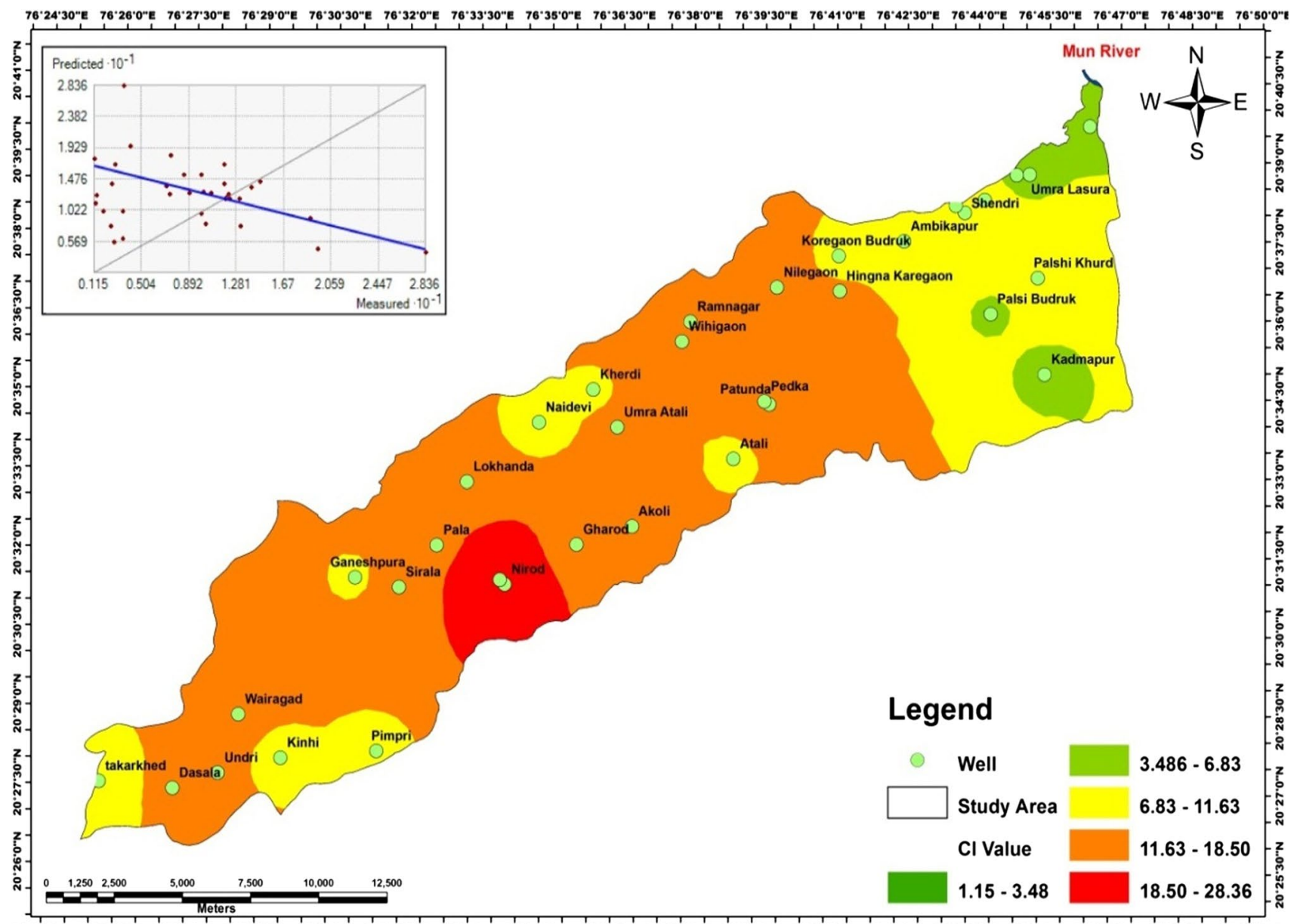

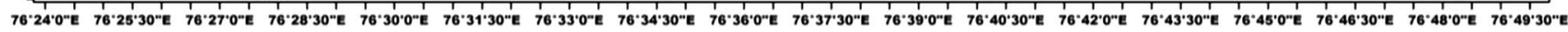

Fig. 8 Spatial distribution map of $\mathrm{Cl}$ of 2013 post-monsoon

suitability of water for many types of uses. In this study, TDS concentration was high due to the presence of bicarbonates, carbonates, sulphates, chlorides and calcium. TDS can be removed by reverse osmosis, electro dialysis, exchange and solar distillation process. It is the concentration of nonvolatile substances present in the water in molecular dispersed and colloidal state. Due to surface and subsurface

Table 2 Range of TDS With Reference To Water Quality

\begin{tabular}{ll}
\hline T D S & Water quality \\
\hline$<1000$ & Fresh \\
$1000-10000$ & Brackish \\
$10,000-1,00,000$ & Saline \\
$>1,00,000$ & Brine \\
\hline
\end{tabular}

movement of water, it contains a wide variety of dissolved inorganic chemical constituent in various amounts. Fundamentally, it is based on concentration of $\mathrm{NaCl}$, which in turn determines the conductivity which has a bearing on TDS. TDS values were observed minimum and maximum ranges of 272.01-356.16 and 573.49-657.56 during post monsoon. Minimum TDS (268.32) was observed in Balapur, Palsi Kh., Palsi Bk. and Dasala villages, while maximum TDS (707.95) was observed in Atali, Kherdi and Umera Atali villages in the basaltic hard rock (Fig. 7 and Table 2).

\section{Calcium (Ca)}

It is one of the alkaline earth metals widely distributed in earth crust and abundant as a cation in groundwater. In the presence of $\mathrm{CO}_{2}$, Calcium bicarbonates can normally be dissolved up to $20 \mathrm{ppm}$ at atmospheric pressure and up to 


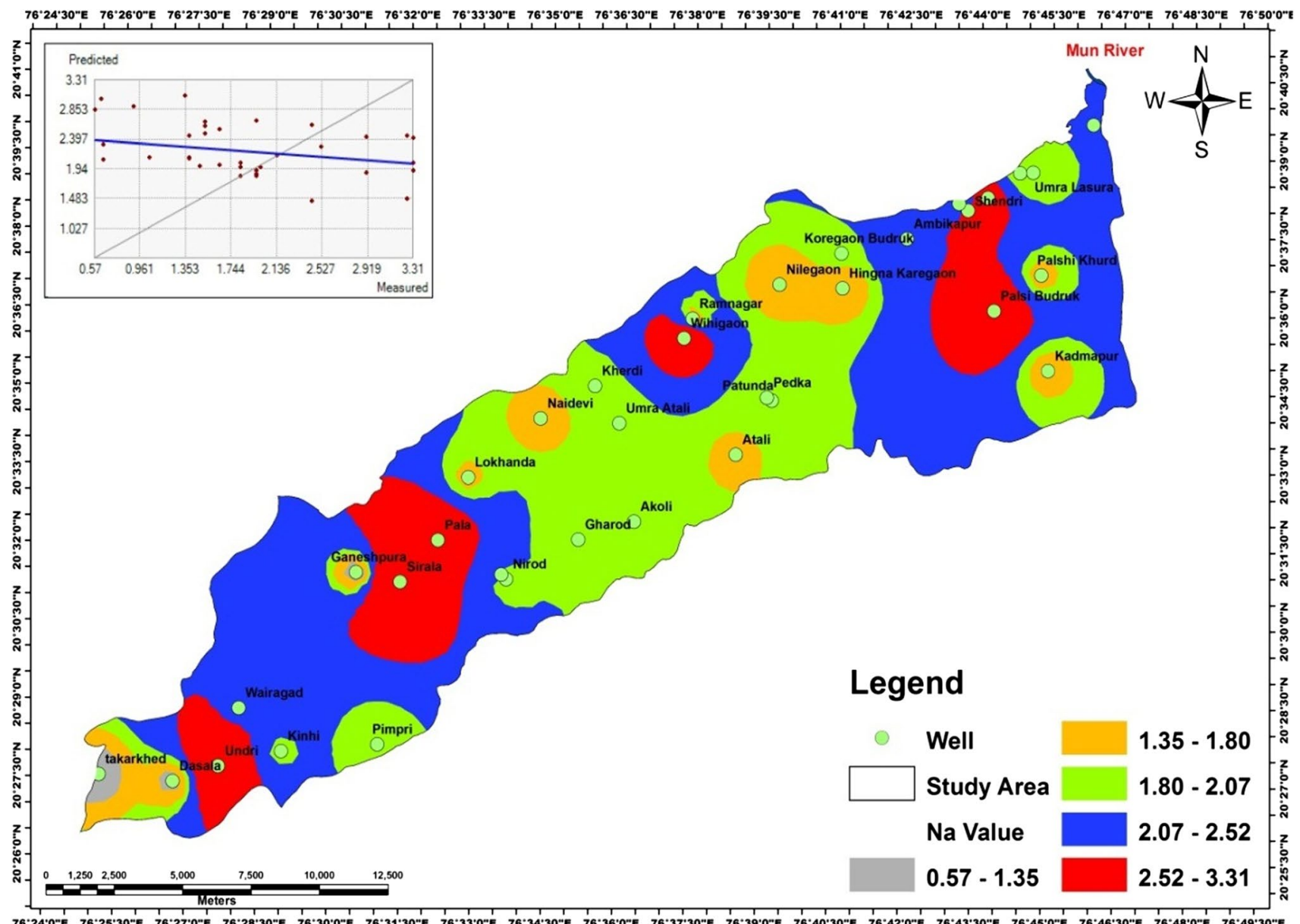

Fig. 9 Spatial distribution map of $\mathrm{Na}$ of 2013 post-monsoon

$100 \mathrm{ppm}$ at higher pressure. The concentration may higher in water coming from limestone zone. The values of calcium in water sample of study area are equalized by chemical analysis. The observation 2013 post-monsoon of $\mathrm{Ca}$ value in Basaltic hard rock minimum ranges 2.35-7.24. The minimum value (2.32) was observed in Kdmpur, Ganeshpur villages and maximum value (7.24) in Kherdi and Umera Atali villages (Fig. 7).

\section{Chloride (Cl)}

Chloride also occurs in bedrock cementing material, connate fluid inclusions and as crystals deposited during or after deposition of sediment. Chlorides in groundwater are originated from various sources including the dissolution of halite and related minerals, marine water entrapped in sediments and anthropogenic sources. Although chloride is often an important dissolved constituent in groundwater contamination from sewage and various types of industrial wastes, chloride is a widely distributed element in all types of rocks in one or the other form and its affinity towards sodium is high. In case of high temperature and reduced rainfall conditions, the chloride concentration is found to be high. Soil porosity and permeability also shows their key role in building up chlorides concentration. Chloride is the member of halogen group of element and present in all natural water at greatly varying concentration which depends on the geochemical condition. Chloride containing water can be recognized of soil, discharge of effluents from chemical industries, all of this affected surface may result in local contamination of both surface and ground 


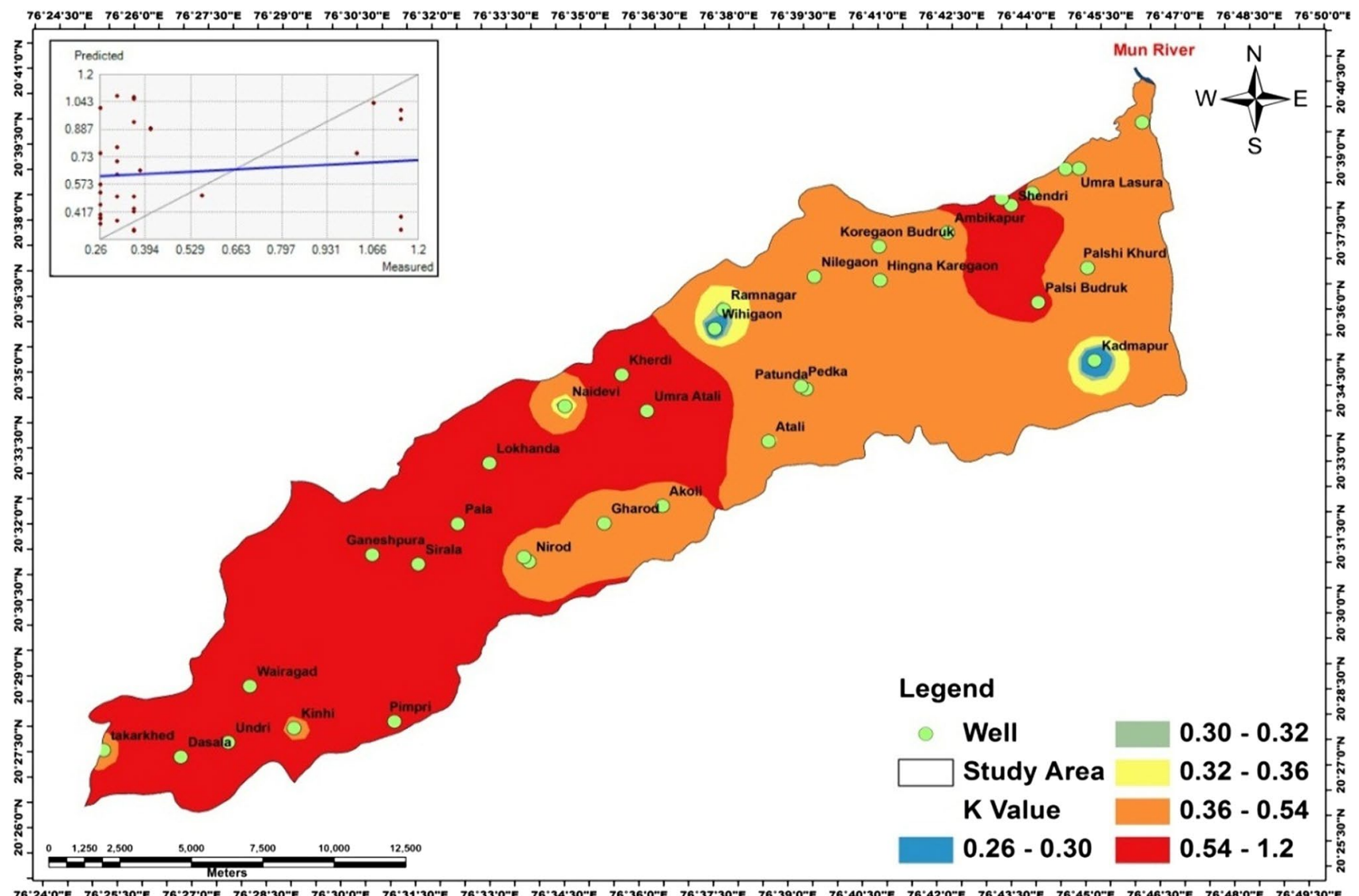

Fig. 10 Spatial distribution map of K 2013 post-monsoon

water, when chlorides concentration of $250 \mathrm{mg} / \mathrm{lit}$ is present along with sodium ions, a salty taste was observed. In this present study 2013 post-monsoon higher values were observed in Nirod villages and lower values are reported in Palsi Bk, Kadmpur and Balapur villages shown in Fig. 8. The salty taste may be absent in water in the absence of sodium ion; even concentration of chlorides is high as $1000 \mathrm{mg} / \mathrm{l}$. Chloride in drinking water originates from natural sources, sewage, industrial effluents, and urban runoff containing saline intrusion by WHO (2004).

\section{Sodium (Na)}

Groundwater for irrigational needs could be gauged by the salinity—-sodium hazards. A significant relationship has been identified between values of sodium in irrigation water and extent to which sodium is absorbed by the soils. High salt concentration in water leads to the formation of saline soil, while high sodium leads to development of an alkaline soil. If the proportion of sodium is high, then the alkali hazard will be high. Sodium is released in groundwater due to weathering of plagioclase feldspar, clay mineral and amphiboles. The observation of the $\mathrm{Na}$ value in study area ranges between 0.57 and 3.31 for post-monsoon 2013. Sodium distribution map indicates the high sodium distribution towards $\mathrm{Na}$ maximum value (3.31) was observed in Palsi Bk., Shendri, Wihigaon, Sirala, Pala and Undri and minimum value $(0.57)$ was observed in Dasala, Takarkhed and Ganeshpur villages for post-monsoon 2013 (Fig. 9).

\section{Potassium (K)}

Potassium in many respects is similar to sodium. In groundwater, potassium is released due to weathering of igneous rocks rich in orthoclase, microcline and biotite. The 


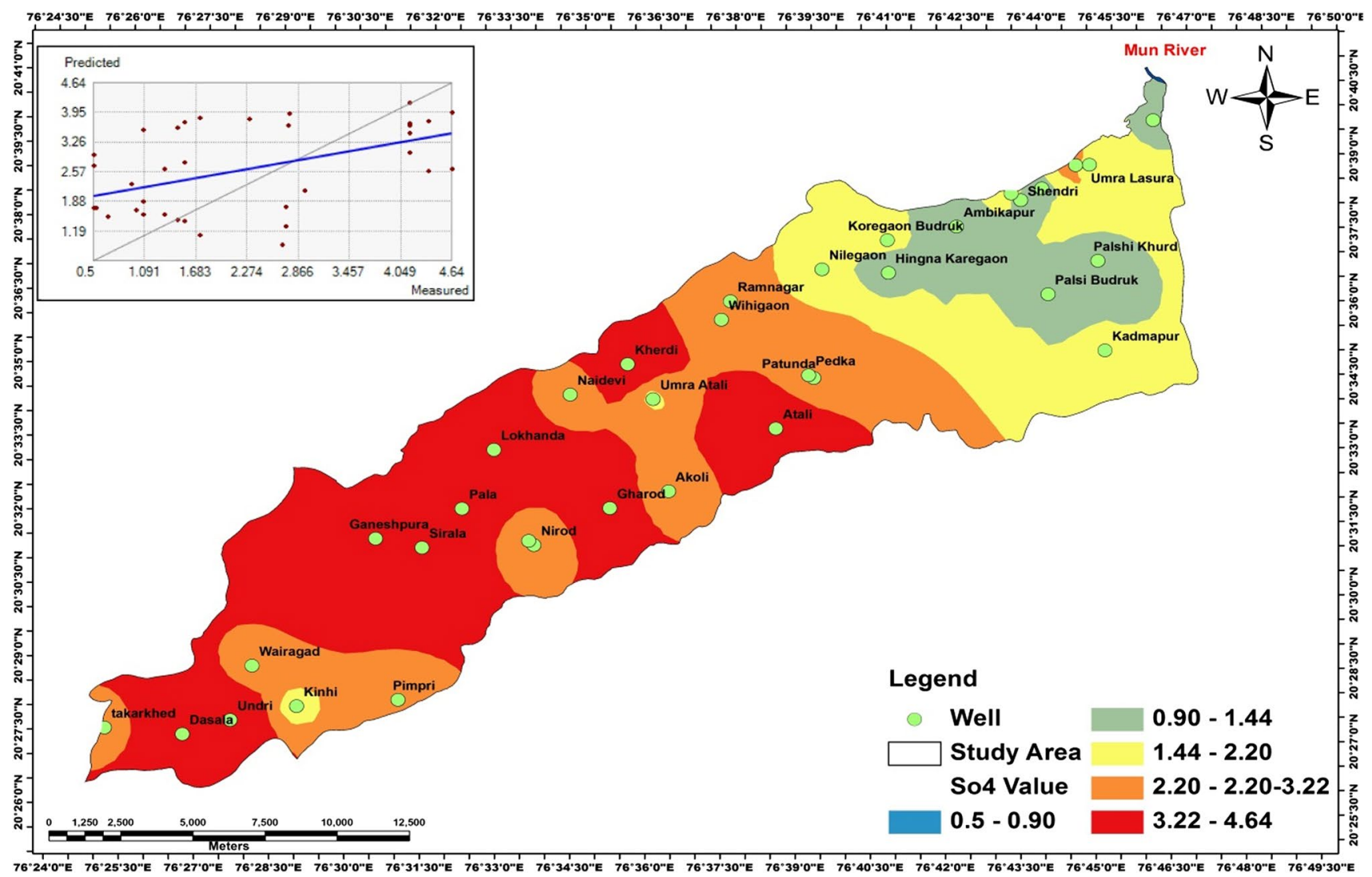

Fig. 11 Spatial distribution map of $\mathrm{So}_{4}$ of 2013 post-monsoon

observation of the potassium value in study area ranges between 0.26 and 1.2 for post-monsoon 2013, respectively. Potassium distribution map (Fig. 10) indicates the high potassium $\mathrm{K}$ distribution towards $\mathrm{K}$ maximum values (1.2) was observed in Ambikapur, Kherdi, UmraAtali, Lokhanda, Pala, Sirala, Kinhi, Undri etc. and minimum values (0.26) was observed in Wihigaon and Kadmapur villages during post-monsoon 2013.

\section{Sulphates $\left(\mathrm{SO}_{4}\right)$}

Sulphates occur in natural water at concentration up to $50 \mathrm{mg} / \mathrm{l}$ concentration. If $1000 \mathrm{mg} / \mathrm{l}$ can be found in water having contact with certain geological formation, rain water has quite high concentration of sulphate particularly on area with high atmospheric, pollution in humid region; sulphate is ready leached from the zone of weathering by infiltrating water and surface run off. The observation of the $\mathrm{SO} 4$ value in study area ranges between 0.5 and 4.64 for post-monsoon 2013. Sulphate distribution map (Fig. 11) indicates the high
SO4 distribution towards the western-central part and lower value observed towards north and eastern part of the study area. In semiarid and arid region, the sulphate is mostly accumulated in the top horizon of soil by physico-chemical reaction with soil colloids.

\section{Bicarbonate $\left(\mathrm{HCO}_{3}\right)$}

The minimum concentration of $\mathrm{HCO}_{3}$ in the study area is measured to be $1.03 \mathrm{meq} / 1$ so that the groundwater of the study area is grouped as "super-carbonated water". The carbonate and bicarbonates are found to be higher in the central part as well as north central part of the basin.

Lower values of carbonate and bicarbonates are reported in lower central part of basin. In this present study area, $\mathrm{HCO}_{3}$ value ranges between 1.07 and 11.16. The distribution of sodium is high in Khardi and Pardi villages, while lower $\mathrm{HCO}_{3}$ is observed in Kinhi, Undari villages, etc. (Figures 12, 13). 


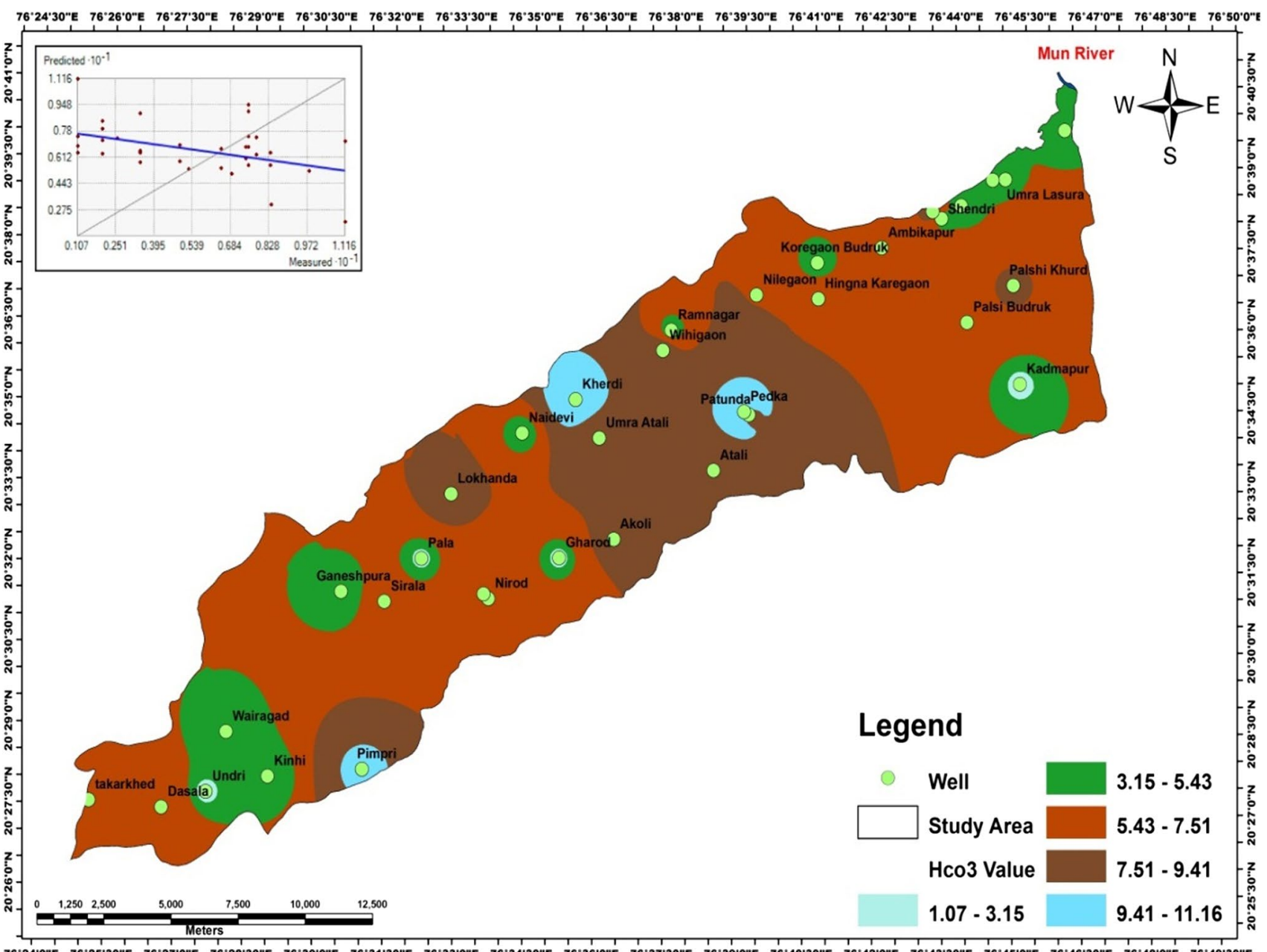

Fig. 12 Spatial distribution map of $\mathrm{HCO}_{3}$ of 2013 post-monsoon

\section{Hydro-geochemical facies}

The hydro-geochemical development of groundwater quality understands by using piper plotting and mapping the concentrations of main cations and anions in the piper trilinear diagram (Piper 1944). The environment and spreading of hydro-chemical facies was determined by providing understandings into how groundwater quality changes within and between aquifers in Basaltic hard rock. Piper trilinear plotting was used to define the hydro-geochemical facies, because they graphically show the associations between the most important dissolved constituents in an establishment of groundwater quality samples. The hydro-geochemistry of groundwater quality in the basin area was calculated using the concentrations of major cations $(\mathrm{Ca} 2+, \mathrm{Mg} 2+$, $\mathrm{Na}+$ and $\mathrm{K}+$ ) and anions $\left(\mathrm{HCO}_{3}^{-}, \mathrm{SO}_{4}^{2-}\right.$ and $\left.\mathrm{Cl}^{-}\right)$in meq/l. The hydro-geochemical facies for groundwater quality in the area is displayed in piper diagram (Fig. 14). The piper plotting shows that $\mathrm{Na}$ is the main cation and $\mathrm{Cl}$ is the major anion.

\section{Conclusion}

1. This study demonstrates the use of spatial interpolation and statistical methods in mapping of groundwater quality parameters in basaltic hard rock in the Akola and 


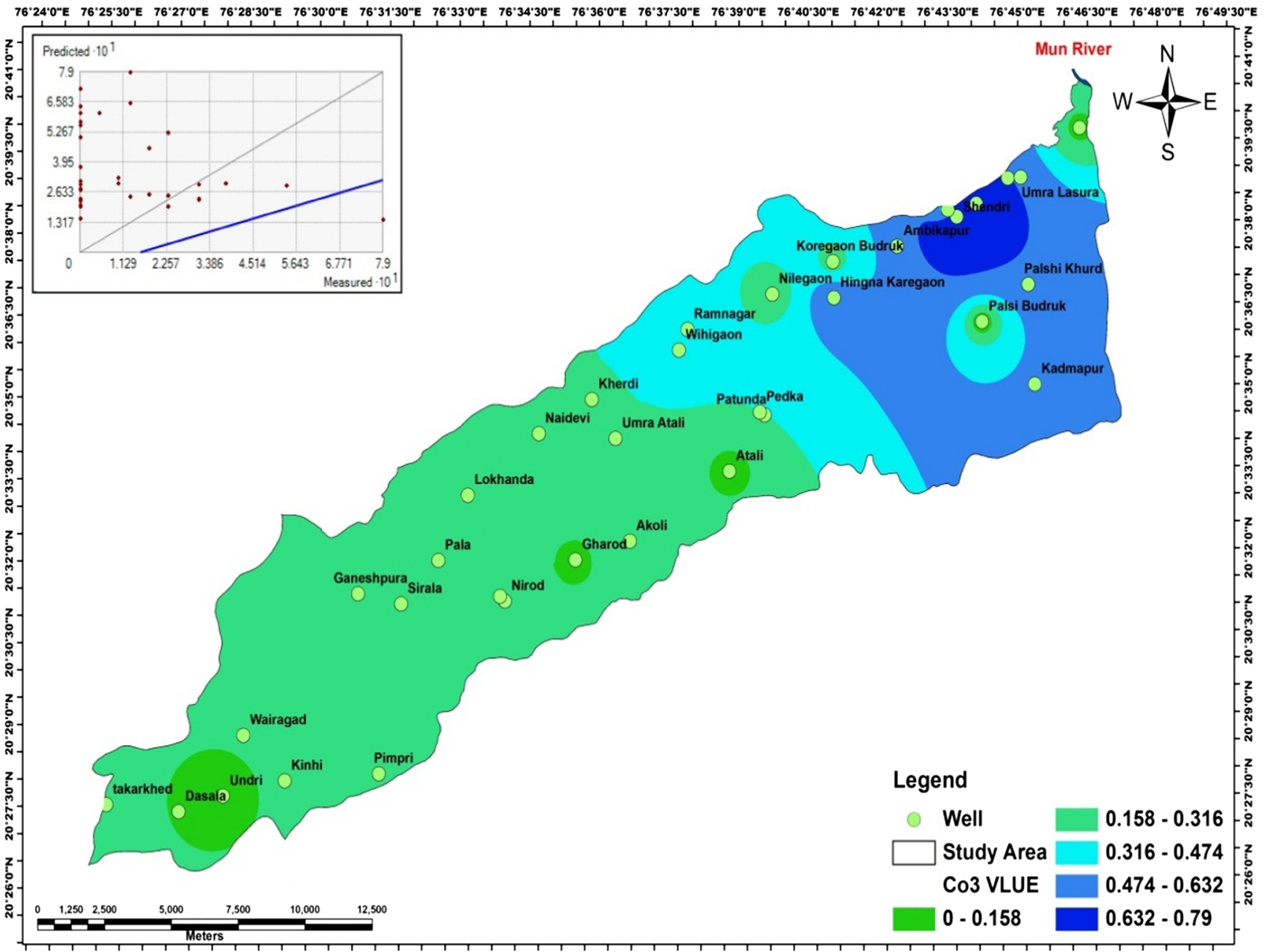

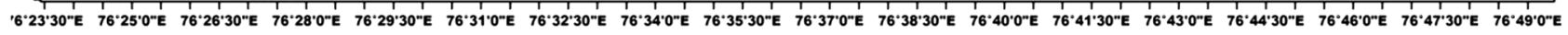

Fig. 13 Spatial distribution map of $\mathrm{Co}_{3}$ of 2013 post-monsoon

Buldhana districts of Maharashtra, India. Groundwater quality exceeded limits for drinking use for most ions at certain locations. Groundwater quality of different water samples in Basaltic hard rock has been analysed and evaluated. Therefore, the groundwater samples were collected from wells located in basin area. The groundwater quality parameters were studied to investigate the water quality for drinking and irrigation. Arc GIS software has been used for groundwater quality parameters analysis and spatial mapping of big storage of data and result making so that groundwater quality constructed studies have done successfully.

2. The study of hydrochemistry parameters was dominated by alkali and strong acids. As per comparison with WHO and ISI standard, $80 \%$ of groundwater has potable for domestic and drinking purpose with few irregularities. The spatial difference maps in the groundwater quality parameters were observed different values in the basaltic hard rock area. The present study of groundwater quality maps can be used for irrigation and drinking purpose in the saline area.

3. Higher TDS and EC values were observed in westerncentral and eastern-western part of the study area dominated by agricultural practices and industrial dominance. Higher concentration was noted in 2013 post-monsoon season following summer.

4. The present result presented appropriateness of groundwater for drinking and irrigation purposes. The study benefits us to understand the quality of the groundwater resources to improve proper management in area. In this area, Deccan rock weathering, geochemical weathering process and evaporation procedures are the main 
Fig. 14 Piper trilinear plotting representative the hydro-geochemical evolution of groundwater quality

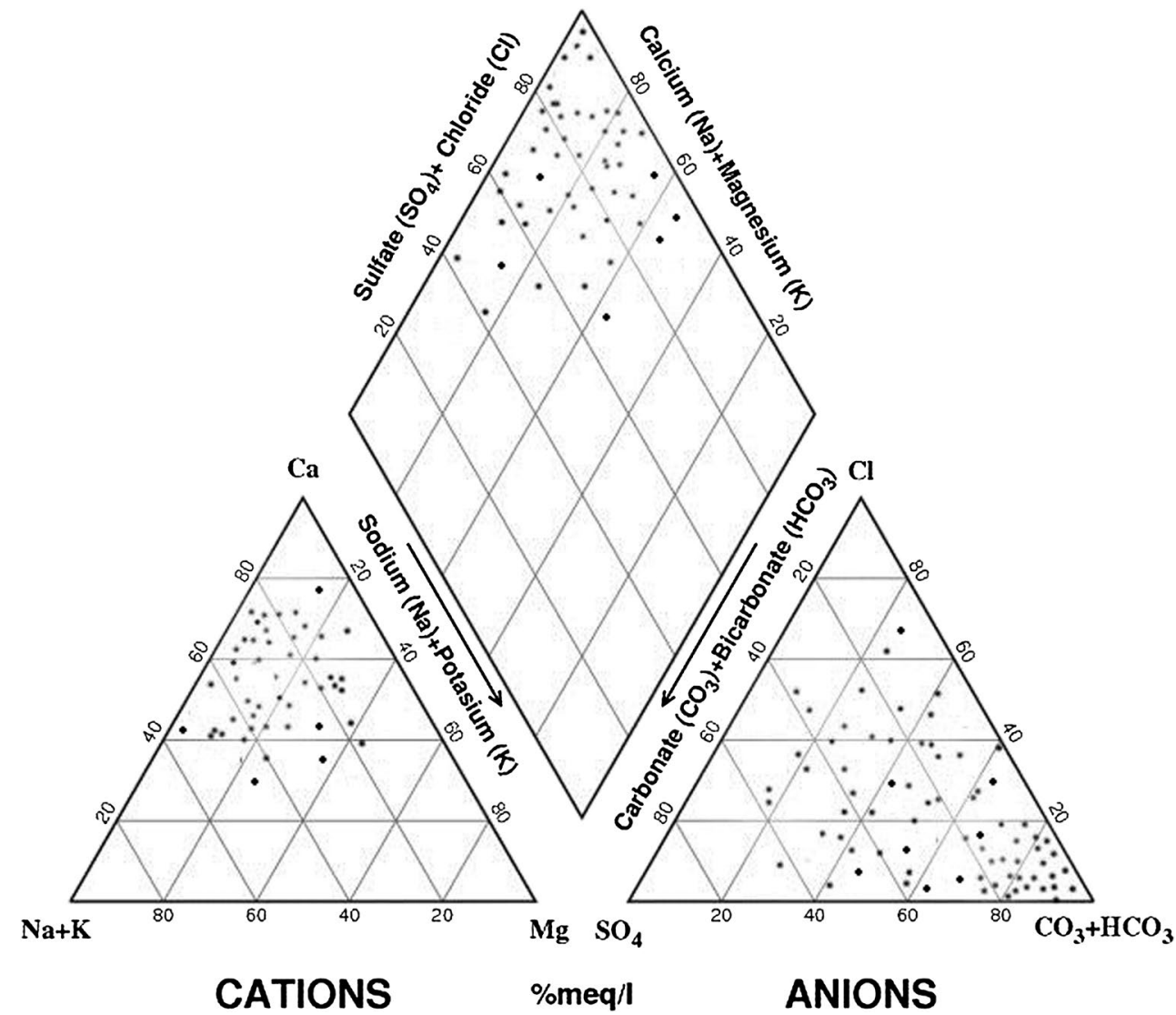

role in hydro-geochemical analysis impact for the concentration of main ions in groundwater quality. In this present study water quality analysis such as minimum and maximum observation values shows $\mathrm{pH}(6.2-8$ on scale), electrical conductivity (348-1598 S/cm), total dissolved solids (268.32-707.95 mg/l), carbonate $(0-30 \mathrm{mg} / \mathrm{l})$, bicarbonate $(0.9-58.9 \mathrm{mg} / \mathrm{l})$, chloride (1.15-28.36 mg/l), sulphate (1S.4-105 mg/l), nitrate (0.4-6.0 mg/l), calcium (2.35-7.24 mg/l), magnesium (2.88-3.73 mg/l), sodium $(0.57-3.31 \mathrm{mg} / \mathrm{l})$, potassium $(0.26-1.2 \mathrm{mg} / \mathrm{l})$, sulphate $(0.5-4.64 \mathrm{mg} / \mathrm{l})$, bicarbonate + carbonate $(1.07-11.16 \mathrm{mg} / \mathrm{l})$ and carbonate $(0-0.79 \mathrm{mg} / \mathrm{l})$.

Open Access This article is distributed under the terms of the Creative Commons Attribution 4.0 International License (http://creativeco mmons.org/licenses/by/4.0/), which permits unrestricted use, distribution, and reproduction in any medium, provided you give appropriate credit to the original author(s) and the source, provide a link to the Creative Commons license, and indicate if changes were made.

\section{References}

APHA (American Public Health Association) (1998) Standard methods for the examination of water and wastewater, 20th edn. American Public Health Association/American Water Works Association/Water Environment Federation, Washington

Arslan H (2013) Application of multivariate statistical techniques in the assessment of groundwater quality in seawater intrusion area in Bafra Plain, Turkey. Environ Monit Assess 185(3):2439-2452

BIS (2000) Indian standard drinking water specification. Bureau of Indian Standard, New Delhi

Buchanan S, Triantafilis J (2009) Mapping water table depth using geophysical and environmental variables. Ground Water 47:80-96

Burrough PA, McDonnell RA (1998) Principles of geographical information systems. Oxford University Press, Oxford

CGWB (2010) Ground water quality in shallow aquifers of India. Central Ground Water Board, Ministry of Water Resources, Government of India, Faridabad

Chen L, Feng Q (2013) Geostatistical analysis of temporal and spatial variations in groundwater levels and quality in the Minqin oasis, Northwest China. Environ Earth Sci 70:1367-1378

El-Hames AS, Al-Ahmadi M, Al-Amri N (2011) A GIS approach for the assessment of groundwater quality in Wadi Rabigh aquifer, Saudi Arabia. Environ Earth Sci 63(6):1319-1331

Elumalai V, Brindha K, Sithole B, Lakshmanan E (2017) Spatial interpolation methods and geostatistics for mapping 
groundwater contamination in a coastal area. Environ Sci Pollut Res. https://doi.org/10.1007/s11356-017-8681-6

Gong G, Mattevada S, O'Bryant SE (2014) Comparison of the accuracy of kriging and IDW interpolations in estimating groundwater arsenic concentrations in Texas. Environ Res 130:59-69

Khadri SFR, Pande C, Moharir K (2013) Groundwater quality mapping of PTU-1 Watershed in Akola district of Maharashtra India using geographic information system techniques. Int J Sci Eng Res. 4(9). ISSN 2229-5518. Impact Factor: 1.4

Moharir K, Pande C, Patil S (2017) Inverse modeling of aquifer parameters in basaltic rock with the help of pumping test method using MODFLOW software. Geosci Front Elsevier J, vol 8, pp. 1-13. Impact Factor 4.256, ISSN: 1674-9871

Piper AM (1944) A graphic procedure in geochemical interpretation of water analysis. Trans Am Geophys Union 25(6):914-928

Sarath Prasanth SV, Magesh NS, Jitheshlal KV, Chandrasekar N, Gangadhar K (2012) Evaluation of groundwater quality and itssuitability for drinking and agricultural use in the coastal stretch of Alappuzha District, Kerala, India. Appl Water Sci 2(3): $165-175$

Selvam S, Manimaran G, Sivasubramanaian P, Balasubramanaian N, Seshunarayana T (2014) GIS-based evaluation of water quality index of groundwater resources around Tuticor in coastal city, South India. Environ Earth Sci 71:2847-2867
Srinivas Y, Hudson Oliver D, Stanley Raj A, Chandrasekar N (2013) Evaluation of groundwater quality in and around Nagercoil town, Tamil Nadu, India: an integrated geochemical and GIS approach. Appl Water Sci 3:631-651

Subramani T, Elango L, Damodarasamy SR (2005) Groundwater quality and its suitability for drinking and agricultural use in Chithar River basin, Tamil Nadu, India. Environ Geol 47(8):1099-1110

Vodela JK, Renden JA, Lenz SD, Mc Elhenney WH, Kemppainen BW (1997) Drinking water contaminants (arsenic, cadmium, lead, benzene and trichloroethylene). 1. Interaction of contaminants with nutritional status on general performance and immune function in broiler chickens. PoultSci 76:1474-1492

Whittemore DO, Greggor KMM, Marotz GA (1989) Effects of variations in recharge on groundwater quality. J Hydrol 106:131-145

WHO (2004) Guidelines for drinking water quality, vol 1. Recommendations, 3rd edn. WHO, Geneva, p 515

Publisher's Note Springer Nature remains neutral with regard to jurisdictional claims in published maps and institutional affiliations. 